\title{
Eğitim Yöneticilerinin Küreselleşme Bağlamında Okullardaki Eğitim Teknolojileri ve Uygulamaları Hakkındaki Görüşleria
}

\author{
İsmail Erol ${ }^{\mathrm{b}}$, Semih Çayak ${ }^{\mathrm{c}, \mathrm{d}}$
}

Özet

Anahtar Kelimeler

$\mathrm{Bu}$ araştırmanın amacı okul müdürlerinin teknoloji liderliği rollerini yerine getirme düzeylerine ilişkin öğretmen algılarını incelemek ve eğitim yöneticilerinin küreselleşme bağlamında okullardaki eğitim teknolojileri ve uygulamaları hakkındaki görüşlerini tespit etmektir. Araştırma, Tekirdağ ilinde görev yapmakta olan 302 öğretmen ve 30 okul yöneticisi ile yürütülmüştür. Araştırmada karma yöntem araştırma desenlerinden sıralı açıklayıcı desen tercih edilmiştir. Veri toplama aracı olarak "Teknoloji Liderliği Ölçeği" ve yarı yapılandırılmış görüşme formu kullanılmıştır. Araştırma sonucunda; okul müdürlerinin teknoloji liderliği rollerini gerçekleştirmelerine ilişkin öğretmen algılarının orta düzeyde olduğu ve ilkokullarda görev yapan öğretmenlerin okul müdürlerinin teknoloji liderliği rollerini gerçekleştirmelerine ilişkin algılarının diğer kademelerde görev yapmakta olan öğretmenlere göre daha yüksek olduğu bulunmuştur. Ayrıca okul yöneticilerinin okullarını küresel bir okul olarak algılamalarında okullarının yeterli teknolojik donanıma sahip olma durumu, uluslararası projeler ve yurt dışı deneyimlerin etkili olduğu bulunmuştur.

\section{Perceptions of Educational Administrators about Educational Technologies and Applications in Schools in the Context of Globalization}

\begin{abstract}
The aim of this research is to examine the perceptions of teachers about the level of school principals fulfilling their technology leadership roles and to determine the views of educational administrators about educational technologies and practices in schools in the context of globalization. The research was carried out with 302 teachers and 30 school administrators working in Tekirdağ. Sequential explanatory design among the mixed-method research designs was preferred in the study. "Technology Leadership Scale" and semi-structured interview form were used as data collection tools. Findings obtained from the research showed that school principals perform their technology leadership roles at a moderate level. As a result of the research; it was found that the perceptions of the teachers regarding the realization of the technology leadership roles of the school principals were at a moderate level and the perceptions of teachers working in primary schools regarding the realization of technology leadership roles of school principals were higher than those of teachers working at other levels. In addition, it has been found that the school principals' perception of their school as a global school, having sufficient technological equipment, international projects and experiences abroad are effective.
\end{abstract}

Keywords

Technology Leadership

Educational Technology

Globalization

Educational Administrator

About Article

Received: 29.06 .2021

Accepted: 15.12 .2021

Doi: 10.18026/cbayarsos.959224

a Bu çalışmanın ilk hali 17-18 Aralık 2020 tarihinde Yıldız Teknik Üniversitesi'nde düzenlenen VII. Yıldız Uluslararası Sosyal Bilimler Kongresinde bildiri olarak sunulmuştur.

b Öğr. Gör. Dr., Tekirdağ Namık Kemal Üniversitesi, Tekirdağ/Türkiye, ORCID: 0000-0001-8531-6001

c Dr., Milli Eğitim Bakanlığı, İstanbul/Türkiye, ORCID: 0000-0003-4360-4288.

d İletişim Yazarı: semihcayak@gmail.com 


\section{Giriş}

Küreselleşme kavramı günümüzde siyasetten ekonomiye, sosyal politikalardan kültüre kadar hemen hemen her alanda meydana gelen değişimleri ifade etme adına kullanılan "sihirli" bir söylem haline gelmiş; geçmiş ve geleceğin kapılarını açmak adına kullanılan bir anahtar gibi görülmeye başlanmış ve "parola gibi kullanılan ve moda olan bir deyim" haline dönüşmüştür (Çalık ve Sezgin, 2005). Dolayısıyla literatürde her alana özgü yapılmış çok farklı küreselleşme tanımlarınına rastlamak mümkündür. Ancak genel anlamda küreselleşme kavramı Power (2000)'ın da belirttiği üzere yeni bilgi teknolojileri ve imkânlarının ortaya çıkması ile beraber oluşan değişimlerin bulunduğu çok boyutlu bir işlev ya da insanların hayatlarını daha detaylı, daha fazla ve daha süratli birleştiren "daralmakta olan mekânlar, azalmakta olan zaman ve yok olmakta olan sınırlar" olarak tanımlanabilir.

Teknolojik alanda meydana gelen gelişmeler küreselleşme sürecini hızlandırmakta ve toplumları her alanda etkilediği gibi eğitim sistemlerini de değiştirmekte ve geliştirmektedir. Küreselleşme süreçlerinde eğitim; sürekli olarak öğrenmeyi, bilgi edinmeyi, bilgili insanlar olabilmeyi, bilgiyi üretebilmeyi, bilgi ile yaşayabilmeyi sağlayan bir süreci temsil eder. $\mathrm{Bu}$ açıdan küreselleşme sürecinde teknoloji ve bilgi önemli bir yer tutmaktadır ve eğitimcilerden de bilgi unsurlarını ve iletişim teknolojilerini kullanan ve yararlı hale dönüştüren bireyler olmaları beklenmektedir (Dağlı, 2007). Ayrıca bu süreçte eğitim yöneticilerinden de eğitimin amaçlarına ulaşabilme adına öğretmenlerini etkileme sürecinde teknolojiyi ve teknolojik imkânları etkili bir biçimde kullanmaları beklenmektedir. İşte bu noktada teknoloji liderliği; teknolojinin ve teknolojik imkânların eğitimin tüm paydaşlarına özümsetilmesi ve teknolojik unsurların gelişimi ile oluşacak rekabetçi alanda eğitim kurumlarının güçlendirilmesi adına eğitim yöneticilerinden beklenen yeterlilik ve becerileri kapsar (Öztaban, 2020). Özellikle teknoloji lideri eğitim yöneticileri denildiği zaman teknolojik uygulama ve çalışmaların geliştirilmesi ve okullarda yaygınlaştırılması adına öğretmenlerin ve izleyenlerin motivasyonunu arttıran ve onlar adına imkânlar sağlayan yöneticiler akla gelmektedir (Watts, 2009). Bu sebeple eğitim yöneticileri küreselleşme sürecinde özelikle eğitim teknolojileri ve uygulamaları ile ilgili olarak gelişmeleri yakından takip etmeli, öğretmenlerine öğretmeöğrenme süreçlerinde meydana gelen teknolojik değişmeleri aktarmalı, tanıtmalı ve bu gelişmekte olan teknolojileri kurumlarında kullanmaları adına gerekli şartları sağlamalıdır (Creighton, 2003).

Eğitim uygulamalarında özellikle Covid-19 pandemisi sonrasında okullarda teknolojik imkânlar ve teknolojik altyapı yeterlilikleri yeniden sorgulanır hale gelmiştir. Öğretmenler ve öğrencilerle beraber, eğitim yöneticilerinin de küreselleşme bağlamında okulların teknolojik imkânlarını yenilemek için adımlar atması istenmiştir. İşte bu süreçte eğitimdeki teknolojik atılımı gerçekleştirebilme için eğitim yöneticilerinin bilgi iletişim teknolojilerini eğitim sisteminin önemli bir parçası olarak görmesi gerekir (Bilig, Sherry ve Havelock, 2005, s.1001).

Türk milli eğitim sistemi içerisinde sadece Covid-19 pandemisi sürecinde değil, daha önceki eğitim uygulamaları sürecinde de eğitim teknolojilerine yatırım yapılmaya başlandığı söylenebilir (Fatih projesi, akıllı tahtalar, projeksiyonlu sinıflar, her sinıfa bir bilgisayar uygulamaları vb.). Ancak özellikle bu süreçtre nitelikli eğitim yöneticilerinden, okullarının teknolojik altyapısını sorgulayıcı, geliştirici ve yenileyici özelliklere sahip olması beklenir. Zira Richardson, Bathon, Flora ve Lewis (2012, s. 145) ise küresel bağlamda eğitimde teknoloji liderliğinin etkisinin giderek arttığını belirtmektedir. Bu nedenle eğitim yöneticilerinden bilgi teknolojilerini kullanarak okulları değiştirme ve geliştirme adına sorumluluk almalaları 
beklenmektedir. Nitekim teknolojik bakımdan modern anlayışa sahip, küresel seviyede yetenek ve bilgi sahibi, uygulanabilir becerilere haiz, geleceği açık vatandaşların son yüzyılın bilgi temelinde gelişen ekonomiye katkı sağlayacak temelde yetiştirilmesi; okullarda gerçekleştirilecek değişikliklere teknolojik yenilikleri bütüncül bir biçimde birleştirerek öncülük edebilecek bir okul liderlerini gerektirir (McLeod ve Richardson, 2011).

Küreselleşen dünyamızın dijital teknoloji çağ1 içerisinde olduğunu varsayarsak, eğitimde teknoloji liderliği daha da önem kazanmaktadır (Chang, 2012). Bu açıdan bu araştırmanın amacı küreselleşen dünyada özellikle sürekli değişim ve gelişime uğrayan eğitim sistemlerinde bir nevi moderatörlük görevi üstlenen eğitim yöneticilerinin teknoloji liderliği rollerini yerine getirme düzeylerine ilişkin öğretmenlerin algıları belirlemek ve okul müdürlerinin okullarındaki eğitim teknolojileri ve uygulamaları hakkındaki görüşlerini incelenmektir. Bu araştırma ile eğitim yöneticilerinin kendi okullarındaki teknolojik şartları değerlendirmesi, bu şartlar ile ilgili analizlerde bulunması ve bu analizlerin sonuçlarının gelecek eğitim araştırmalarına katkı sağlaması beklenmektedir. Çünkü teknolojik liderlik, eğitim kurumlarının tamamında bilgi teknolojilerinin etkili bir biçimde kullanımını kolay hale getiren örgütsel politika, eylem ve kararları simgelemektedir (Anderson ve Dexer, 2005, s.80). Unutulmamalıdır ki, gelişmiş bir bilgi teknolojisine sahip olduğumuz bu çağda teknoloji ürünleri; okullar, öğretmenlerin ve öğrencilerin daha iyi eğitim alması adına önemli bir etkiye sahiptir (Hsieh, Yen ve Kuan, 2014). Bu süreçte eğitim yöneticilerinin okullarının sahip olduğu teknolojik imkânlar ve bu teknolojik imkânların sağlayabileceği eğitim uygulamaları olanakları hakkındaki görüşleri önem arz etmektedir. Bu düşünceden hareketle bu araştırmanın amacı öğretmen algılarına göre okul müdürlerinin teknoloji liderliği rollerini yerine getirme düzeylerini ve okul müdürlerinin küreselleşme bağlamında okullardaki eğitim teknolojileri ve uygulamaları hakkındaki görüşlerini incelemektir. Bu amaç doğrultusunda araştırmada aşağıdaki sorulara yanıtlar aranmıştır:

1. Öğretmenlerin, okul müdürlerinin teknoloji liderliği rollerini yerine getirme düzeylerine ilişkin algıları nasıldır?

2. Öğretmenlerin, okul müdürlerinin teknoloji liderliği rollerini yerine getirme düzeylerine ilişkin algıları "öğretmenlerin cinsiyetlerine", "okul müdürlerinin cinsiyetlerine" ve "okul müdürünün görev yaptığı eğitim kademesine" göre anlamlı bir farklılık göstermekte midir?

3. Okul müdürlerinin küresel bir okul olmaya ilişkin görüşleri nelerdir?

4. Okul müdürlerinin eğitimde teknoloji kullanımına ilişkin görüşleri nelerdir?

\section{Yöntem}

\section{Araştırmanın Deseni}

Öğretmen algılarına göre okul müdürlerinin teknoloji liderliği rollerini yerine getirme düzeyleri ve okul müdürlerinin küreselleşme bağlamında okullardaki eğitim teknolojileri ve uygulamaları hakkındaki görüşlerinin incelendiği bu araştırmada karma yöntem araştırma desenlerinden sıralı açıklayıcı desen tercih edilmiştir. Açılayıcı desende önce araştırmanın nicel kısmı daha sonra nitel kısmı yapılmaktadır (Creswell, 2003). Araştırmanın nicel boyutu tekil tarama modeliyle, nitel boyutu ise nitel araştırma desenlerinden olgubilim deseniyle tasarlanmıştır. 
Karma yöntem araştırmalarının "çeşitleme (triangulation), tamamlama (complementarity), geliştirme (development), başlatma (initiation) ve genişletme (expansion)" olmak üzere beş önemli işlevi bulunmaktadır (Greene, Caracelli \& Graham,1989). Bu araştırmada karma yöntemin tercih edilmesinin nedeni tamamlayıcılık (complementarity) olarak belirlenmiştir. Tamamlayıcılıkta; nitel ve nicel yöntemler araştırma problemi ile ilgili farklı boyutları incelemek için kullanılır. Bu farklı boyutlara ilişkin elde edilen sonuçlar birbirini tamamlayarak araştırma problemine ilişkin daha kapsamlı bir sonuç ortaya koyar (Yıldırım ve Şimşek, 2013). Diğer bir ifadeyle bir yöntemden elde edilen bulguların detaylandırılması, sunulması, arttırılması ve açıklığa kavuşturulmasında diğer yöntemden elde edilen sonuçlar kullanır (Baki ve Gökçek, 2012, s. 4). Bu bağlamda çalışmada önce nicel araştırma yapılacak ve daha sonra yapılacak olan yüz yüze görüşmelerle bulgular zenginleştirilecektir.Araştırma makalelerinde, buraya yöntem kısmı eklenmeli ve yöntemden sonra varsa, alt başlıklara (ikinci, üçüncü düzey başlıklar) yer verilmelidir.

\section{Araştırma Grupları}

Araştırmanın örneklem türü hem olasılıklı örnekleme hem de amaçlı örnekleme tekniklerinin birlikte kullanıldığı sıralı karma yöntem örneklemesi olarak seçilmiştir. Sıralı karma yöntem örneklemi, bir karma yöntem çalışması için olasılıklı ve amaçlı örnekleme stratejileri "NicelNitel" ya da "Nitel-Nicel" şeklinde sıralı biçimde örneklem seçilmesini kapsar (Baki ve Gökçek, 2012, s. 7). Bu araştırmada da önce ölçek uygulanmış ve daha sonra ise görüşmeler yapılmıştır (nicel-nitel). Nicel araştırmaya dahil edilecek katılımcıların belirlenmesinde basit tesadüfi örnekleme yöntemi, nitel araştırmaya dahil edilecek katılımcıların belirlenmesi için ise amaçlı örnekleme yöntemlerinden maksimum çeşitlilik örneklemesi yöntemi kullanılmıştır. Nicel araştırmanın evrenini 2020-2021 eğitim-öğretim yılı birinci döneminde Tekirdağ ilindeki resmi okullarda (ilkokul, ortaokul ve lise) görev yapmakta olan öğretmenler oluşturmaktadır. Araştırmanın örneklemini ise bu öğretmenler arasından basit tesadüfü örnekleme yöntemi kullanılarak seçilen 302 öğretmen oluşturmuştur. Örneklem grubuna ait öğretmenlerin 229'u (\%76) kadın, 73'ü (\%24) erkektir. Öğretmenlerin 20'si (\%7) ilkokulda, 25'i (\%8) ortaokulda ve 257'si (\%85) ise lisede görev yapmaktadır. Öğretmenlerin okul müdürlerinin 49'u (\%16) kadın, 253'ü (\%84) erkektir. Nitel araştırmanın çalışma grubunu ise Tekirdağ ilinde görev yapmakta olan 30 okul yöneticisi oluşturmuştur. Okul yöneticilerinin 7'si (\%23) kadın, 23'ü (\%77) ise erkektir. Okul yöneticilerinin 12'si (\%40) ilkokulda, 11'i (\%37) ortaokulda ve 7'si (\%23) lisede görev yapmaktadır.

\section{Veri Toplama Araçları}

Araştırmada veri toplama aracı olarak kişisel bilgi formu, Sincar (2009) tarafından geliştirilen “Teknoloji Liderliği Ölçeği” ve araştırmacılar tarafından hazırlanan yarı yapılandırılmış görüşme formu kullanılmıştır.

\section{Kişisel Bilgi Formu}

Araştırmacı tarafından hazırlanan kişisel bilgi formunda katılımcıların cinsiyetlerine, mesleki kıdemlerine, eğitim durumlarına ve görev yaptıkları eğitim kademelerine yönelik sorulara yer verilmiştir. 


\section{Nicel Veri Toplama Aracı}

\section{Teknoloji Liderliği Ölçeği}

Teknoloji Liderliği Ölçeği, Sincar (2009) tarafından öğretmen algılarına göre okul yöneticilerinin teknoloji liderliği rollerini gerçekleştirme düzeylerini belirlemek amacıyla geliştirilmiştir. İlk hali 29 madde ve 4 alt boyuttan oluşan ölçeğin geçerlik ve güvenirlik çalışmaları Öztaban (2020) tarafından yeniden yapılmıştır. Yeniden düzenlenen Okul Yöneticilerinin Teknoloji Liderliği Ölçeği; 15 maddeden ve üç alt boyuttan oluşmaktadır. Ölçeğin üç faktörlü yapısı toplam varyansın \%75.47'ini açıklamaktadır ve yapılan doğrulayıcı faktör analizi sonucu da 3 faktörlü yapının uyum indeksi değerlerinin kabul edilebilir düzeyde olduğunu göstermiştir $\left(\mathrm{x}^{2} / \mathrm{df}=2.75\right.$, RMSEA= .07, NFI= .98, CFI= .99). Cronbach Alpha iç tutarlık katsayısı "genel teknoloji liderliği (ölçek toplam puanı)" için .94, "insan odaklılık" alt boyutu için .89, "vizyon ve destek" alt boyutu için .93 ve "iletişim ve işbirliği" alt boyutu için .91 olarak hesaplanmıştır

Ölçek maddeleri; beşli Likert tipinde olup, (1) hiç katılmıyorum, (2) katılmıyorum, (3) kısmen katılıyorum, (4) katılıyorum, (5) tamamen katılıyorum olarak derecelendirilmiştir. Ölçeğin boyutları incelendiğinde insani odaklılık boyutu, okul yöneticilerinin öğretmenlerin ve öğrencilerin gereksinimlerini dikkate alması ve alınacak kararlarda öğretmen ve öğrencileri öncelikle insani değeriyle düşünmesi; vizyon ve destek boyutu okul yöneticilerinin, yönetsel ve eğitimsel faaliyetlerde teknolojiyi etkin kullanması, teknoloji entegrasyonu için vizyon oluşturması ve vizyona uygun olarak öğretmen ve öğrencilerin sınıf içi uygulamalarında kullanacağı uygun teknolojileri okula kazandırması ve son boyut olan, iletişim ve işbirliği boyutu ise okul yöneticilerinin yönetim ve eğitim paydaşlarının etkileşiminde en etkin iletişim araçlarının kullanması ile ilgilidir. Ölçek puanı hesaplanırken ölçekteki soruların toplam puanı alınmıştır. Ölçek puanının artması öğretmenlerin, okul yöneticilerinin teknoloji liderliği rollerini gerçekleştirme düzeylerini daha yüksek algıladıklarını göstermektedir.

\section{Nitel Veri Toplama Arace}

\section{Yarı Yapılandırılmış Görüşme Formu}

Okul müdürlerinin küreselleşme bağlamında okullardaki eğitim teknolojileri ve uygulamaları hakkındaki görüşlerini tespit etmek amacıyla araştırmacılar tarafından beş sorudan oluşan "Yarı Yapılandırılmış Görüşme Formu" hazırlanmıştır. Yarı yapılandırılmış görüşme tekniği araştırmada görüşmenin seyrine bağlı olarak araştırmacının farklı sorularla görüşmeye yön verebileceği ve görüşülen kişinin cevaplarını daha fazla açmasına yardımcı olabileceği bir tekniktir (Türnüklü, 2000). Bu bağlamda oluşturulan görüşme formunun araştırmanın amacına uygun olup olmadığı, araştırma sorularının kapsam geçerliliğinin sağlanması için nitel araştırma konusunda çalışmaları olan üç uzmandan görüş alınarak gelen görüşler doğrultusunda görüşme formu yeniden yapılandırılmıştır. Daha sonra dört okul yöneticisi ile pilot görüşmeler yapılmış ve sorularda dil veya anlam bakımından anlaşılmayan yönler tekrar değerlendirilerek görüşme formuna son hali verilmiştir. Görüşmeler araştırmacılar tarafından yürütülmüş̧ür ve tüm görüşmeler ses kayıt cihazı ile kayıt altına alınmıştır. Ardından kayıt altına alınan yanıtlar bilgisayar ortamına aktarılmıştır.

\section{İşlemler ve Verilerin Analizi}

Veri toplama sürecinde öncelikle araştırma için gerekli olan yasal izinler alınmıştır. Daha sonra Google formlar aracılığıyla hazırlanan ölçek linki araştırmaya gönüllü olarak katılmak 
isteyen öğretmenlere okul yönetimi tarafından iletilmiştir. Öğretmenler tarafından doldurulan 302 ölçeğe ait verilerle analiz yapılmıştır. Araştırmanın nitel bölümüne ait veriler ise 30 okul yöneticisi ile yapılan görüşmeler neticesinde elde edilmiştir. Her bir görüşme yaklaşık olarak 30-40 dakika sürmüştür.

Analizlere başlamadan önce verilerin normallik varsayımlarını karşılayıp karşılamadığı incelenmiştir. Bu amaç doğrultusunda verilerin çarpıklık ve basıklık değerleri incelenmiştir. Kalaycı'ya (2014, s. 8) göre, basıklık-çarpıklık değerinin -2 ile +2 arasında yer alması verilerin normal dağılım sergilediğini göstermektedir. Bu bilgiden hareketle okul müdürlerinin teknoloji liderliği ölçeğinin geneline ve alt boyutlarına ait puanların normal dağılım sınırları içerisinde bulunduğu görülmüştür (Tablo 1). Araştırmada aritmetik ortalamaların yorumlanmasında 1.00-1.79 aralığ1 "çok düşük", 1.80-2.59 aralığ 1 "düşük", 2.60-3.39 aralığ1 “orta", 3.40-4.19 aralığ1 "yüksek" ve 4.20-5.00 aralığ1 "çok yüksek" olarak değerlendirilmiştir. Araştırmada nicel verilerin analizinde betimleyici istatistikler, bağımsız gruplar t-testi ve tek yönlü varyans analizi (Anova) kullanılmıştır. Verilerin analizi IBM SPSS 25.0 paket programıla gerçekleştirilmiştir. Ortalamalar arasında farkın anlamlı olup olmadığını belirlemek üzere .05 anlamlılık düzeyi esas alınmıştır.

Araştırmada nitel verilerin analizinde içerik analizi tekniği kullanılmıştır. İçerik analizinin temel amacı toplanan verileri açıklayabilecek kavramlara ve ilişkilere ulaşmaktır. Bu amaç doğrultusunda içerik analizinde veriler öncelikle kodlanmaktadır. Daha sonra birbiriyle ilişkili olan kodlar bir araya getirilerek temalar oluşturulmaktadır (Yıldırım ve Şimşek, 2003). $\mathrm{Bu}$ araştırmada da veriler öncelikle kodlanmış ve ardından anlamlı bir bütün oluşturacak şekilde birbiriyle ilgili olan kodlar bir araya getirilerek alt temalar ve temalar oluşturulmuştur. Ayrıca nitel bulguların geçerliğinin sağlanması amacıyla katılımcıların görüşlerinden bire bir alıntılar yapılmıştır. Okul yöneticileri ile ilgili betimleyici içerik verilirken M1, M2, M3... şeklinde numaralandırılarak kodlanmışlardır. Ayrıca kodlamalarda okul yöneticilerinden kaç katılımcının aynı görüşte olduğunu göstermek amacıyla kodlamaların yanına frekans (f) değerleri yazılmıştır. Araştırmanın nitel boyutuna ilişkin bulguların güvenirliğinin sağlanmasında Miles ve Huberman'ın (1994) öngördüğü formül kullanılmıştır. Bu formül Güvenirlik=(Görüş Birliği)/(Görüş Birliği+Görüş Ayrılığı) şeklindedir. Bu formül kullanılırken okul yöneticilerinin görüşleri için aynı kodun kullanması durumunda görüş birliği, farklı bir kodun kullanılması durumunda da görüş ayrılığı olarak kabul edilmiştir. Araştırmacıların ayrı ayrı yaptıkları kodlamalar karşılaştırılarak uzlaşma yüzdesi hesaplanmıştır. Buna göre araştırmada uzlaşma yüzdesinin .83 olduğu görülmüştür. Uzlaşma yüzdesinin \%70'in üzerinde olması araştırmanın güvenilir olduğunu göstermektedir.

\section{Etik Kurul İzni}

$\mathrm{Bu}$ araştırmanın etik kurulu izni Tekirdağ Namık Kemal Üniversitesi Bilimsel Araştırma ve Yayın Etik Kurulu tarafından 09.06.2021 tarihli T2021-648 sayılı oturumda Karar-10 sayısıyla alınmıştır. 


\section{Bulgular}

Bu bölümde araştırmanın nicel ve nitel boyutlarına ilişkin bulgular ayrı başlıklar halinde ele alınmıştır.

\section{Araştırmanın Nicel Boyutuna İlişkin Bulgular}

Öğretmen algılarına göre okul müdürlerinin teknoloji liderliği rollerini ne düzeyde gerçekleştirdiklerini belirlemek için ölçeğin tümünün ve alt boyutlarının aritmetik ortalama ve standart sapma değerleri hesaplanmış ve Tablo 1'de sunulmuştur.

Tablo 1. Teknoloji Liderliği Ölçeğinin Alt Boyutlarına Göre Aritmetik Ortalama ve Standart Sapma Değerleri

\begin{tabular}{lcccccc}
\hline Alt Boyutlar & Madde Sayısı & $\mathbf{n}$ & $\overline{\mathbf{X}}$ & ss & Çarpıklık & Basıklık \\
\hline İnsan Odaklılık & 4 & 302 & 3,25 & 0,92 &,- 33 &, 01 \\
Vizyon ve Destek & 6 & 302 & 3,07 & 0,96 &,- 09 &,- 32 \\
İletişim ve İşbirliği & 5 & 302 & 3,02 & 0,96 &,- 20 &,- 29 \\
Toplam & 15 & 302 & 3,10 & 0,86 &,- 14 &,- 12 \\
\hline
\end{tabular}

Tablo 1 incelendiğinde teknoloji liderliği ölçeğini oluşturan alt boyutların aritmetik ortalama değerleri en yüksekten en küçüğe doğru "insan odaklılık" ( $\bar{x}=3.25)$, "vizyon ve destek" ( $\bar{x}=$ $3,07)$ ve "iletişim ve iş birliği" $(\bar{x}=3,02)$ 'dir. Teknoloji liderlik ölçeği'nin tümünün aritmetik ortalama değerlerine bakıldığında madde başına düşen aritmetik ortalama değerinin $\bar{x}=3,10$ olduğu görülmektedir. Bu değerin de "kararsızım" aralığında yer aldığı görülmektedir. Bu bulguya dayanarak öğretmenlerin verdiği yanıtlara göre, okul yöneticilerinin genel teknoloji liderliği rollerini yerine getirme düzeyleri görece orta düzeyde olduğu söylenebilir.

Örneklem grubunu oluşturan öğretmenlerin teknoloji liderliği ölçeği toplam ve alt boyut puanlarının cinsiyet değişkenine göre anlamlı bir farklılık gösterip göstermediğini belirlemek amacıyla bağımsız gruplar $t$ testi yapılmıştır.

Tablo 2. Teknoloji Liderliği Ölçeği Toplam ve Alt Boyut Puanlarının Öğretmenlerin Cinsiyetlerine Göre Farklılaşıp Farklılaşmadığını Belirlemek Üzere Yapılan Bağımsız Gruplar t Testi Sonuçları

\begin{tabular}{|c|c|c|c|c|c|c|c|c|}
\hline \multirow{2}{*}{ Puan } & \multirow{2}{*}{ Gruplar } & \multirow{2}{*}{$n$} & \multirow{2}{*}{$\overline{\mathrm{x}}$} & \multirow{2}{*}{ ss } & \multirow{2}{*}{$\mathrm{Sh}_{\bar{x}}$} & \multicolumn{3}{|c|}{$t$ Testi } \\
\hline & & & & & & $t$ & sd & $p$ \\
\hline \multirow{2}{*}{ İnsan Odaklılık } & Kadın & 229 & 3,27 & ,91 &, 06 & \multirow{2}{*}{.79} & \multirow{2}{*}{300} & \multirow{2}{*}{.428} \\
\hline & Erkek & 73 & 3,17 & 97 & ,11 & & & \\
\hline \multirow{2}{*}{ Vizyon ve Destek } & Kadın & 229 & 3,12 & 96 & ,06 & \multirow{2}{*}{1.68} & \multirow{2}{*}{300} & \multirow{2}{*}{.094} \\
\hline & Erkek & 73 & 2,91 & ,94 & ,11 & & & \\
\hline \multirow{2}{*}{ İletişim ve İşbirliği } & Kadın & 229 & 3,05 & ,95 & ,06 & \multirow{2}{*}{1.06} & \multirow{2}{*}{300} & \multirow{2}{*}{.29} \\
\hline & Erkek & 73 & 2,92 & 97 & 11 & & & \\
\hline \multirow{2}{*}{ Toplam } & Kadın & 229 & 3,14 & ,86 & ,06 & \multirow{2}{*}{1.37} & \multirow{2}{*}{300} & \multirow{2}{*}{.172} \\
\hline & Erkek & 73 & 2,98 & ,86 &, 10 & & & \\
\hline
\end{tabular}

Tablo 2'de görüldüğü üzere yapılan bağımsız gruplar $\mathrm{t}$ testi sonucunda insan odaklılık alt boyutu ( $t=.79 ; \mathrm{p}>, 05)$; vizyon ve destek alt boyutu $(\mathrm{t}=1.68 ; \mathrm{p}>, 05)$; iletişim ve işbirliği alt boyutu $(t=1.06 ; p>, 05)$ ve ölçek toplam puanı $(t=1.37 ; p>, 05)$ için grupların aritmetik ortalamaları arasında anlamlı bir farklılık bulunmamıştır. 
Örneklem grubunu oluşturan öğretmenlerin teknoloji liderliği ölçeği toplam ve alt boyut puanlarının okul müdürlerinin cinsiyetlerine göre anlamlı bir farklılık gösterip göstermediğini belirlemek amacıyla bağımsız gruplar t testi yapılmıştır.

Tablo 3. Teknoloji Liderliği Ölçeği Toplam ve Alt Boyut Puanlarının Okul Müdürlerinin

Cinsiyetlerine Göre Farklılaşıp Farklılaşmadığını Belirlemek Üzere Yapılan Bağımsız

Gruplar t Testi Sonuçları

\begin{tabular}{|c|c|c|c|c|c|c|c|c|}
\hline \multirow{2}{*}{ Puan } & \multirow{2}{*}{ Gruplar } & \multirow{2}{*}{$n$} & \multirow{2}{*}{$\overline{\mathrm{X}}$} & \multirow{2}{*}{ SS } & \multirow{2}{*}{$\mathrm{Sh}_{\bar{x}}$} & \multicolumn{3}{|c|}{$t$ Testi } \\
\hline & & & & & & $t$ & $s d$ & $p$ \\
\hline \multirow{2}{*}{ İnsan Odaklılık } & Kadın & 49 & 3,35 & ,92 & 13 & \multirow{2}{*}{.88} & \multirow{2}{*}{300} & \multirow{2}{*}{.38} \\
\hline & Erkek & 253 & 3,23 & ,92 & ,06 & & & \\
\hline \multirow{2}{*}{ Vizyon ve Destek } & Kadın & 49 & 3,19 & ,95 & 14 & \multirow{2}{*}{.98} & \multirow{2}{*}{300} & \multirow{2}{*}{.33} \\
\hline & Erkek & 253 & 3,05 & ,96 & ,06 & & & \\
\hline \multirow{2}{*}{ İletişim ve İşbirliği } & Kadın & 49 & 3,19 & 1,02 & 15 & \multirow{2}{*}{1.37} & \multirow{2}{*}{300} & \multirow{2}{*}{.17} \\
\hline & Erkek & 253 & 2,99 & ,94 & ,06 & & & \\
\hline \multirow{2}{*}{ Toplam } & Kadın & 49 & 3,24 & 88 & 13 & \multirow{2}{*}{1.19} & \multirow{2}{*}{300} & \multirow{2}{*}{.23} \\
\hline & Erkek & 253 & 3,07 & ,86 & 05 & & & \\
\hline
\end{tabular}

Tablo 3'te görüldüğ̈ü üzere yapılan bağımsız gruplar $t$ testi sonucunda insan odaklılık alt boyutu ( $\mathrm{t}=.88 ; \mathrm{p}>, 05)$; vizyon ve destek alt boyutu $(\mathrm{t}=.98 ; \mathrm{p}>, 05)$; iletişim ve işbirliği alt boyutu $(\mathrm{t}=1.37 ; \mathrm{p}>, 05)$ ve ölçek toplam puanı $(\mathrm{t}=1.19 ; \mathrm{p}>, 05)$ için grupların aritmetik ortalamaları arasında anlamlı bir farklılık bulunmamıştır.

Örneklem grubunu oluşturan öğretmenlerin algılarına göre okul müdürlerinin teknoloji liderliği ölçeği toplam ve alt boyut puanlarının eğitim kademesi değişkenine göre anlamlı bir farklılık gösterip göstermediğini belirlemek amacıyla tek yönlü varyans analizi (ANOVA) yapilmiştır.

Tablo 4. Teknoloji Liderliği Ölçeği Toplam ve Alt Boyut Puanlarının Okul Müdürlerinin Görev Yaptığı Eğitim Kademesine Göre Farklılaşıp Farklılaşmadığını Belirlemek Üzere Yapılan Tek Yönlü Varyans Analizi (ANOVA) Sonuçları

\begin{tabular}{|c|c|c|c|c|c|c|c|c|c|c|}
\hline \multicolumn{8}{|c|}{$f, \overline{\mathrm{x}}$ ve $s s$ Değerleri } & \multicolumn{3}{|c|}{ ANOVA Sonuçları } \\
\hline Puan & Grup & $n$ & $\overline{\mathrm{x}}$ & ss & Var. K. & $K T$ & $S d$ & $K O$ & $F$ & $p$ \\
\hline \multirow{4}{*}{ İnsan Odaklılık } & İlkokul & 20 & 3,83 & ,91 & G.Arası & 7.77 & 2 & 3.88 & \multirow{4}{*}{4.68} & \multirow{4}{*}{.010} \\
\hline & Ortaokul & 25 & 3,35 & 87 & G.İçi & 248.17 & 299 & .83 & & \\
\hline & Lise & 257 & 3,19 & ,92 & Toplam & 255.93 & 301 & & & \\
\hline & Toplam & 302 & 3,25 & ,92 & & & & & & \\
\hline \multirow{4}{*}{$\begin{array}{l}\text { Vizyon ve } \\
\text { Destek }\end{array}$} & İlkokul & 20 & 3,68 &, 81 & G.Arası & 9.89 & 2 & 4.94 & \multirow{3}{*}{5.51} & \multirow{4}{*}{,004 } \\
\hline & Ortaokul & 25 & 3,29 &, 81 & G.İçi & 268.27 & 299 & .897 & & \\
\hline & Lise & 257 & 3,00 & ,97 & Toplam & 278.16 & 301 & & & \\
\hline & Toplam & 302 & 3,07 & ,96 & & & & & & \\
\hline \multirow{3}{*}{$\begin{array}{l}\text { İletişim ve } \\
\text { İşbirliği }\end{array}$} & İlkokul & 20 & 3,56 & ,68 & G.Arasi & 6.33 & 2 & 3.16 & \multirow{3}{*}{3.51} & \multirow{3}{*}{.031} \\
\hline & Ortaokul & 25 & 2,92 & ,69 & G.İçi & 269.14 & 299 & .90 & & \\
\hline & Lise & 257 & 2,99 & ,99 & Toplam & 275.46 & 301 & & & \\
\hline
\end{tabular}




\begin{tabular}{llccclcccccc}
\hline \multirow{4}{*}{ Toplam } & Toplam & 302 & 3,02 &, 96 & & & & & & \\
& İlkokul & 20 & 3,68 &, 69 & G.Arası & 7.59 & 2 & 3.79 & & \\
& Ortaokul & 25 & 3,18 &, 69 & G.İçi & 216.22 & 299 & .72 & 5.25 & ,006 \\
& Lise & 257 & 3,05 &, 87 & Toplam & 223.81 & 301 & & & \\
& Toplam & 302 & 3,10 &, 86 & & & & & & \\
\hline
\end{tabular}

Tablo 4'te görüldüğü üzere yapilan tek yönlü varyans analizi (ANOVA) sonucunda insan odakl1lı alt boyutu $(\mathrm{F}=4.68 ; \mathrm{p}<, 05)$; vizyon ve destek alt boyutu $(\mathrm{F}=5,51 ; \mathrm{p}<, 01)$; iletişim ve işbirliği alt boyutu $(\mathrm{F}=3.51 ; \mathrm{p}<, 05)$ ve ölçek toplam puanı $(\mathrm{F}=5,25 ; \mathrm{p}<, 01)$ için grupların aritmetik ortalamaları arasındaki farklılık anlamlı bulunmuştur. İnsan odaklılık, vizyon ve destek ve iletişim ve işbirliği alt boyut puanları ile ölçek toplam puanı için saptanan anlamlı farklılığın hangi gruplardan kaynaklandığını belirlemek amacıyla tamamlayıcı analizlere (post-hoc) geçilmiştir. Bu amaç için öncelikle Levene analizi ile varyans homojenliği denetlenmiş ve varyansların homojen olduğu bulunmuştur $\left(\mathrm{LF}_{\mathrm{f}}=.38 ; \mathrm{p}>, 05 / \mathrm{LF}=1,06 ; \mathrm{p}>, 05 / \mathrm{LF}=4.25 ; \mathrm{p}>, 05 / \mathrm{LF}=\right.$ $1,33 ; p>, 05)$. Bu nedenle LSD testi tercih edilmiş elde edilen sonuçlar aşağıda sunulmuştur.

Tablo 5. İnsan Odaklılık Puanlarının Öğretmenlerin Görev Yaptığı Eğitim Kademesi Göre Hangi Gruplar Arasında Farklılaştığını Belirlemek Üzere Yapılan LSD Testi Sonuçları

\begin{tabular}{llccc}
\hline Gruplar (i) & Gruplar (j) & $\bar{x}_{i}-\bar{x}_{j}$ & $\mathrm{Sh}_{\overline{\mathbf{x}}}$ & $p$ \\
\hline \multirow{2}{*}{ İlkokul } & Ortaokul &, 48 &, 27 &, 083 \\
& Lise &, 63 &, 21 &, 003 \\
\multirow{2}{*}{ Ortaokul } & İlkokul &,- 48 &, 27 &, 083 \\
& Lise &, 16 &, 19 &, 404 \\
\multirow{2}{*}{ Lise } & İlkokul &,- 63 &, 21 &, 003 \\
& Ortaokul &,- 16 &, 19 &, 404 \\
\hline
\end{tabular}

Tablo 5'te görüldügü üzere örneklem grubunu oluşturan öğretmenlerin teknoloji liderlik ölçeğinin insan odaklılık alt boyutundan aldıkları puanların eğitim kademesi değişkenine göre hangi gruplar arasında anlamlı farklılıklar gösterdiğini belirlemek amacıyla yapılan LSD testi sonucunda söz konusu farklılığın, ilkokullarda görev yapan öğretmenlerle liselerde görev yapan öğretmenler arasında ilkokullarda görev yapan öğretmenler lehine $\mathrm{p}<, 05$ düzeyinde; lisede görev yapan öğretmenlerle ilkokulda görev yapan öğretmenler arasında lisede görev yapan öğretmenler lehine $\mathrm{p}<, 01$ düzeyinde gerçekleştiği belirlenmiştir. Diğer grupların aritmetik ortalamaları arasındaki farklılıklar ise anlamlı bulunmamıştır ( $p>, 05)$.

Tablo 6. Vizyon ve Destek Puanlarının Öğretmenlerin Görev Yaptığı Eğitim Kademesi Göre Hangi Gruplar Arasında Farklılaştığını Belirlemek Üzere Yapılan LSD Testi Sonuçları

\begin{tabular}{llccc}
\hline Gruplar (i) & Gruplar (j) & $\bar{x}_{i}-\bar{x}_{j}$ & $\mathrm{Sh}_{\overline{\mathrm{x}}}$ & $p$ \\
\hline \multirow{2}{*}{ İlkokul } & Ortaokul &, 40 &, 28 &, 164 \\
& Lise &, 68 &, 22 &, $\mathbf{0 0 2}$ \\
\multirow{2}{*}{ Ortaokul } & İlkokul &,- 40 &, 28 &, 164 \\
& Lise &, 28 &, 20 &, 152 \\
Lise & İlkokul &,- 68 &, 22 &, 002 \\
& Ortaokul &,- 28 &, 20 &, 152 \\
\hline
\end{tabular}


Tablo $6^{\prime}$ da görüldüğü üzere örneklem grubunu oluşturan öğretmenlerin teknoloji liderliği ölçeği vizyon ve destek alt boyutundan aldıkları puanların eğitim kademesi değişkenine göre hangi gruplar arasında anlamlı farklılıklar gösterdiğini belirlemek amacıyla yapılan LSD testi sonucunda söz konusu farklılığın, ilkokulda görev yapan öğretmenlerle lisede görev yapan öğretmenler arasında ilkokulda görev yapan öğretmenler lehine $\mathrm{p}<, 01$ düzeyinde gerçekleştiği belirlenmiştir. Diğer grupların aritmetik ortalamaları arasındaki farklılıklar ise anlamlı bulunmamıştır ( $\mathrm{p}>, 05)$.

Tablo 7. İletişim ve İşbirliği Puanlarının Öğretmenlerin Görev Yaptığı Eğitim Kademesi Göre Hangi Gruplar Arasında Farklılaştığını Belirlemek Üzere Yapılan LSD Testi Sonuçları

\begin{tabular}{llccc}
\hline Gruplar (i) & Gruplar (j) & $\bar{x}_{i}-\bar{x}_{j}$ & $\mathrm{Sh}_{\overline{\mathbf{x}}}$ & $p$ \\
\hline \multirow{2}{*}{ İlkokul } & Ortaokul &, 64 &, 28 & $\mathbf{, 0 2 5}$ \\
& Lise &, 57 &, 22 & $\mathbf{, 0 1 0}$ \\
\multirow{2}{*}{ Ortaokul } & İlkokul &,- 64 &, 28 & $\mathbf{, 0 2 5}$ \\
\multirow{2}{*}{ Lise } & Lise &,- 07 &, 20 &, 728 \\
& İlkokul &,- 57 &, 22 & $\mathbf{, 0 1 0}$ \\
\hline
\end{tabular}

Tablo 7'de görüldüğü üzere örneklem grubunu oluşturan öğretmenlerin teknoloji liderliği ölçeği iletişim ve işbirliği alt boyutundan aldıkları puanların eğitim kademesi değişkenine göre hangi gruplar arasında anlamlı farklılıklar gösterdiğini belirlemek amacıyla yapılan LSD testi sonucunda söz konusu farklılığın, ilkokulda görev yapan öğretmenlerle ortaokulda görev yapan öğretmenler arasında ilkokulda görev yapan öğretmenler lehine $p<, 05$ düzeyinde gerçekleştiği; ilkokulda görev yapan öğretmenlerle lisede görev yapan öğretmenler arasında ilkokulda görev yapan öğretmenler lehine $p<, 05$ düzeyinde gerçekleştiği belirlenmiştir. Diğer grupların aritmetik ortalamaları arasındaki farklılıklar ise anlamlı bulunmamıştır ( $p>, 05)$.

Tablo 8. Toplam Puanın Öğretmenlerin Görev Yaptı̆̆ı Eğitim Kademesi Göre Hangi Gruplar Arasında Farklılaştığını Belirlemek Üzere Yapılan LSD Testi Sonuçları

\begin{tabular}{llccc}
\hline Gruplar (i) & Gruplar (j) & $\bar{x}_{i}-\bar{x}_{j}$ & $\mathrm{Sh}_{\overline{\mathrm{x}}}$ & $p$ \\
\hline \multirow{2}{*}{ Ilkokul } & Ortaokul &, 50 &, 26 &, 052 \\
& Lise &, 63 &, 20 &, $\mathbf{0 0 2}$ \\
\multirow{2}{*}{ Ortaokul } & İlkokul &,- 50 &, 26 &, 052 \\
& Lise &, 13 &, 18 &, 455 \\
Lise & İlkokul &,- 63 &, 20 &, $\mathbf{0 0 2}$ \\
& Ortaokul &,- 13 &, 18 & 0,399 \\
\hline
\end{tabular}

Tablo 8'de görüldüğü üzere örneklem grubunu oluşturan öğretmenlerin teknoloji liderliği ölçeği ölçek toplam puanlarının eğitim kademesi değişkenine göre hangi gruplar arasında anlamlı farklılıklar gösterdiğini belirlemek amacıyla yapılan LSD testi sonucunda söz konusu farklılığın, ilkokulda görev yapan öğretmenlerle lisede görev yapan öğretmenler arasında ilkokulda görev yapan öğretmenler lehine $p<, 01$ düzeyinde gerçekleştiği belirlenmiştir. Diğer grupların aritmetik ortalamaları arasındaki farklılıklar ise anlamlı bulunmamıştır $(p>, 05)$. 


\section{Araştırmanın Nitel Boyutuna İlişkin Bulgular}

Araştırmanın bu bölümünde okul müdürleriyle yapılan görüşmeler neticesinde elde edilen veriler araştırmacılar tarafından içerik analizi yöntemi ile analiz edilerek temalar, alt temalar ve kodlar şeklinde sunulmuştur. Ayrıca bulgular katılımcılardan yapılan doğrudan alıntılarla desteklenmiştir.

Araştırma sonucunda "görev yapılan okula ilişkin küresellik algısı", "teknolojinin eğitimdeki yerini algılayış”, " teknolojik alt yapı yeterlikleri”, "öğretmenlerin eğitim süreçlerinde teknoloji kullanım durumları”, "eğitimde teknoloji kullanımının öğrenci ve öğretmene etkisi” isimli beş temaya ulaşılmıştır. Her bir temaya ilişkin kodlar aşağıda açılanmıştır.

Görüşme yapılan okul yöneticilerine öncelikle “Okullarını küresel bir okul olarak nitelendirebilecekler mi?" şeklinde soru sorulmuştur. Bu konudaki katılımcı görüşleri okullarını "okullarını küresel bir okul olarak nitelendirenler" ile "okullarını küresel bir okul olarak nitelendirmeyenler" şeklinde iki alt tema altında incelenmiştir (Tablo 9).

Tablo 9. Görev Yapılan Okula İlişkin Küresellik Algısı

\begin{tabular}{|c|c|c|c|}
\hline Tema & Alt Temalar & Kodlar & $\mathrm{f}$ \\
\hline \multirow{9}{*}{ 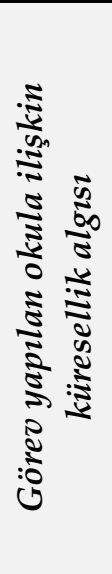 } & \multirow{4}{*}{$\begin{array}{l}\text { Okullarnı küresel bir okul olarak } \\
\text { nitelendirenler }\end{array}$} & Yeterli teknolojiye sahip olma & 13 \\
\hline & & Ulusal ve uluslararası projelere dâhil olma & 3 \\
\hline & & Yurtdışı deneyimleri & 3 \\
\hline & & Yabancı öğrenci ziyaretleri & 1 \\
\hline & \multirow{5}{*}{$\begin{array}{l}\text { Okulların küresel bir okul olarak } \\
\text { nitelendirmeyenler }\end{array}$} & Fiziki ve donanımsal eksilikler & 7 \\
\hline & & Maddi yetersizlikler & 2 \\
\hline & & Çevre ve toplum desteğinin olmaması & 2 \\
\hline & & Yurtdışı programlarının yetersizliği & 1 \\
\hline & & Diğer & 2 \\
\hline
\end{tabular}

Okullarını küresel bir okul olarak nitelendiren yöneticiler bu düşüncelerini okullarının yeterli teknolojik imkana sahip olmasına ( $\mathrm{f}=13)$, okullarının ulusal ve uluslararası projelere katılmış olmalarına ( $\mathrm{f}=3)$, yurtdışı deneyimleri olmasına ( $\mathrm{AB}$ projeleri vs.) $(\mathrm{f}=3)$, yabancı öğrenci ziyaretlerine (Türki Cumhuriyetlerden gelen öğrenciler) $(\mathrm{f}=1)$ bağlamaktadır. Okullarını küresel bir okul olarak nitelendiremeyen yöneticiler bu düşüncelerini okullarındaki fiziksel ve donanımsal eksikliklere ( $f=7)$, maddi yetersizliklere $(\mathrm{f}=2)$, çevre desteğinin olmamasına $(\mathrm{f}=2)$, Yurtdışı programların yetersizliğine $(\mathrm{f}=1)$ ve diğer $(\mathrm{f}=2)$ bazı nedenlere bağlamaktadır.

Ortaya çıkan kategorilerdeki frekansı en yüksek olan kodlara ilişkin katılımcı görüşlerinden bazıları şöyledir:

Okullarda aslında yeterli teknolojik imkanlar varsa, öğrenciler dünya üzerinde neler olup bittiğini daha rahat anlayabiliyor. Ĕğer ben bir yönetici olarak bu olanakları sınıflarıma sunabiliyorsam, okulumun küreselleşme bağlamında gelişebileceğgini dile getirebilirim. (M3)

Özellikle ilkokul ve ortaokullarda, straların bile bazen yetersiz kalabildiği durumlar oluyor, biz hala küresel dünyaya adapte olamadık. Donanım eksikliklerimiz var. Bunları tamamlamadan, teknolojik olarak ilerleme boyutuna geçeceğimizi sanmıyorum. (M17) 
Görüşme yapılan okul yöneticilerine eğitim teknolojilerinin kendileri için ne anlam ifade ettiği sorulmuştur. Bu konudaki katılımcı görüşleri teknolojinin eğitimdeki yerini algılayış kategorisi altında eğitim teknolojilerinin öğretme ve öğrenme sürecini destekleyici bir unsur olarak teknoloji $(\mathrm{f}=14)$, eğitimin vazgeçilmezi olan bir araç olarak teknoloji $(\mathrm{f}=11)$ ve eğitim sürecinde doğru kullanılması gereken bir unsur olarak teknoloji ( $\mathrm{f}=7$ ) kodlarıyla belirtilmiştir (Tablo 10).

Tablo 10. Teknolojinin Eğitimdeki Yerini Algılayış

\begin{tabular}{|l|l|l|}
\hline Alt Temalar & Kodlar & f \\
\hline \multirow{4}{*}{$\begin{array}{l}\text { Teknolojinin Eğitimdeki Yerini } \\
\text { Algılayış }\end{array}$} & $\begin{array}{l}\text { Öğretme ve öğrenme sürecini destekleyici bir unsur } \\
\text { olarak teknoloji }\end{array}$ & 14 \\
\cline { 2 - 3 } & Eğitimin vazgeçilmezi olan bir araç olarak teknoloji & 11 \\
\cline { 2 - 3 } & $\begin{array}{l}\text { Eğitim sürecinde doğru kullanılması gereken bir unsur } \\
\text { olarak teknoloji }\end{array}$ & 7 \\
\hline
\end{tabular}

Ortaya çıkan kategoride kodlara ilişkin katılımcı görüşlerinden bazıları şöyledir:

Bilgisayarlar, telefonlar, tabletler... Öğrencilerin olduğu kadar, biz yöneticilerin de işini çok kolaylaştırıyor. Ĕ̆itimin iş ve işleyişi çok hızlı hale geliyor teknoloji sayesinde. Zaman eskiden en büyük problemdi. Bu teknolojik gelişmeler, bizi hem hızlandırdı hem de daha kaliteli eğitim olanakları sunmamızı sağladı. (M29)

Sunumların hazırlanması, görselin düzenlenmesi, öğrencilerin derse dikkatinin çekilmesi açısından ciddi oranda işimizi kolaylaştırıyor teknolojik materyaller. (M11)

Görüşme yapılan okul yöneticilerine okullarının eğitim teknolojilerine ilişkin alt yapı durumları sorulmuştur. Bu konudaki katılımcı görüşleri teknolojik alt yapının oldukça yeterli olduğu ( $\mathrm{f}=7$ ), bazı eksiklerin olmasina rağmen yeterli olduğu $(\mathrm{f}=5)$ ve yetersiz olduğu $(\mathrm{f}=3)$ şeklinde belirtilmiştir (Tablo 11).

Tablo 11. Okullarının Ĕ̆itim Teknolojilerine İlişkin Alt Yapı Durumları

\begin{tabular}{|l|l|l|}
\hline Kategori & Kodlar & f \\
\hline \multirow{3}{*}{ Teknolojik alt yapı yeterlikleri } & Oldukça yeterli & 7 \\
\cline { 2 - 3 } & Eksikleri olmakla birlikte yeterli & 5 \\
\cline { 2 - 3 } & Yetersiz & 3 \\
\hline
\end{tabular}

Ulaşılan kodlara ilişkin katılımcı görüşlerinden birisi şöyledir:

Benim okulumda okul aile birliği vasıtası ile tüm sınıfların projeksiyon ihtiyacını giderdik. Sınıflarda kullanılmak üzere wireless desteği sağladık. Bilgisayarsız ve bilgisayarı olmayan öğretmenimiz yoktur.(M7)

Görüşme yapılan okul yöneticilerine okullarındaki öğretmenlerin eğitim süreçlerinde teknoloji kullanım durumlarına ilişkin sorular sorulmuştur. Bu konudaki katılımcı görüşleri teknolojiyi aktif olarak kullanma $(\mathrm{f}=6)$, teknolojiyi kullanmaktan kaçınma $(\mathrm{f}=6$ ) ve teknolojiyi kullanmama ( $\mathrm{f}=3$ ) şeklinde belirtilmiştir (Tablo 12). 
Tablo 12. Öğretmenlerin Eğitim Süreçlerinde Teknoloji Kullanım Durumları

\begin{tabular}{|l|l|l|}
\hline Alt Temalar & Kodlar & f \\
\hline \multirow{4}{*}{$\begin{array}{l}\text { Öğretmenlerin eğitim süreçlerinde teknoloji kullanım } \\
\text { durumları }\end{array}$} & Aktif olarak kullanma & 6 \\
\cline { 2 - 3 } & $\begin{array}{l}\text { Teknolojiyi kullanmaktan } \\
\text { kaçınma }\end{array}$ & 6 \\
\cline { 2 - 3 } & Teknolojiyi kullanmama & 3 \\
\hline
\end{tabular}

Ortaya çıkan kodlara ilişkin katılımcı görüşlerinden bazıları şöyledir:

Benim gördüğ̈̈m ve gözlemlediğim, artık yaşlısı da genci de bilgisayarı, interneti, Whatsapp'ı artık aktif bir şekilde kullanıyor. Bende akademik yayınlar okuyorum. Önceden olsa evet yaşlı öğretmenler çok aktif değildi. Ama artık herkes internete, bilgiye, verilere kolayca erişebilecek altyapıya sahip. (M10)

Özellikle artık teknolojinin hayatımızın bir parçası olması, öğretmenlerin hem ders olanların hazırlamasında, hem dersi sunmasında, hem de değerlendirme süreçlerinde teknoloji ile iç içe olmasına sebebiyet vermektedir. (M3)

Görüşme yapılan yöneticilere eğitimde teknoloji kullanımının öğrencilere ve öğretmenlere ne gibi etkileri olduğuna ilişkin sorular sorulmuştur. Bu konudaki katılımcı görüşleri "eğitim teknolojileri kullanmanın olumlu etkileri" ile "eğitim teknolojileri kullanmanın olumsuz etkileri" şeklinde iki kategori altında incelenmiştir (Tablo 13).

Eğitim teknolojileri kullanmanın olumlu etkileri konusundaki yöneticilerin görüşleri kalıcı öğrenmeyi sağlama(f=8), öğrenme motivasyonunu arttırma ( $f=5)$, öğrencinin konuya ilgisini çekme $(\mathrm{f}=5)$, algılamayı kolaylaştırma( $\mathrm{f}=4)$, zaman tasarrufu sağlama $(\mathrm{f}=3)$, araştırmaya meraklandırma $(\mathrm{f}=3$ ) ve bilgiye erişimi kolaylaştırma $(\mathrm{f}=2)$ şeklinde kodlanmıştır.

Eğitim teknolojileri kullanmanın olumsuz etkileri konusundaki yöneticilerin görüşleri ise teknoloji bağımlılığ1 $(\mathrm{f}=15)$, hazırcılığa teşvik $(\mathrm{f}=7)$, sinıf hakimiyetini zorlaştırma $(\mathrm{f}=5)$ ve materyallerin amaç dışı kullanımı $(\mathrm{f}=4)$ şeklinde kodlanmıştır.

Tablo 13. Eğitimde Teknoloji Kullanımının Öğrenciye ve Öğretmene Etkisi

\begin{tabular}{|l|l|l|}
\hline Kategoriler & Kodlar & $\mathrm{f}$ \\
\hline \multirow{5}{*}{ Ĕgitimde teknoloji kullanımının olumlu etki } & Kalıcı öğrenmeyi sağlama & 8 \\
\cline { 2 - 3 } & Öğrenme motivasyonunu arttırma & 5 \\
\cline { 2 - 3 } & Öğrencinin konuya ilgisini çekme & 5 \\
\cline { 2 - 3 } & Algılamayı kolaylaştırma & 4 \\
\cline { 2 - 3 } & Zaman tasarrufu sağlama & 3 \\
\cline { 2 - 3 } & Araştırmaya meraklandırma & 3 \\
\cline { 2 - 3 } & Bilgiye erişimi kolaylaştırma & 2 \\
\hline \multirow{5}{*}{ Ĕitimde teknoloji kullanımının olumsuz etki } & Teknoloji bağımlılığı & 15 \\
\cline { 2 - 3 } & Hazırcılığa teşvik & 7 \\
\cline { 2 - 3 } & Sınıf hakimiyetini zorlaştırma & 5 \\
\cline { 2 - 3 } & Materyallerin amaç dışı kullanımı & 4 \\
\hline
\end{tabular}


Ortaya çıkan kodlara ilişkin katılımcı görüşlerinden bazıları şöyledir:

Özellikle sunumlar, filmler ve hareketli teknolojik materyaller bizim ilkokul çocuklarının çok ilgisini çekiyor. Çocuklar bayılıyor derste konu ile ilgili bir şeyler izlemeye... Bu yüzden; anlatım yöntemi ve soru cevap yönteminden ziyade, projeksiyon ile ders işlenmesi öğrencide farklı duyu organlarına hitap ettiği için daha kalıcı öğrenme sağhlyor. (M21)

Öğrenciye istediğin kadar dil dök dersi dinlemez. Ama konu ile ilgili bir film aç, slayt hazırla pür dikkat seni dinler. (M19)

\section{Tartışma, Sonuç ve Öneriler}

Bu araştırmada 2020-2021 eğitim-öğretim yılında Tekirdağ ilinde görev yapmakta olan 302 öğretmenin ve 30 okul yöneticisinin küreselleşme bağlamında okullardaki eğitim teknolojileri ve uygulamaları hakkındaki görüşleri incelenmiştir.

Araştırma bulguları öğretmenlerin okul müdürlerinin teknoloji liderliği rollerini gerçekleştirmelerine ilişkin algılarının görece orta düzeyde olduğunu göstermiştir. Ulaşılan bu sonuç, okul yöneticilerinin öğretmenlere teknoloji kullanımına ilişkin destek verdikleri ve bu konuda onların işlerini kolaylaştırdıkları biçiminde yorumlanabilir. Araştırmadan elde edilen bu bulguyu desteler nitelikte literatürde okul yöneticilerinin teknoloji liderliği rolleri ile ilgili yapılan araştırmalar genel olarak okul yöneticilerinin teknoloji liderliği rollerini gerçekleştirme düzeylerinin öğretmenler tarafından orta ve yüksek düzeyde algılandığını göstermektedir (Erden ve Erden, 2007; Sezer, 2011; Sincar ve Aslan, 2011; Öztaban, 2020). Bununla birlikte literatürde okul yöneticilerinin, teknoloji liderliklerini kendi görüşlerine göre değerlendiren bazı araştırmalarda da (Anderson ve Dexter, 2005; Can, 2008; Çalık, Çoban ve Özdemir, 2019; Eren-Şişman, 2010; Kozloski, 2007; Macaulay, 2009; Yu ve Durrington, 2006) okul yöneticilerinin kendilerini genel olarak yüksek düzeyde yeterli gördükleri görülmüştür.

Araştırmadan elde edilen diğer bulgulara göre okul müdürlerinin teknoloji liderliği rollerini gerçekleştirmelerine ilişkin öğretmen algıları ölçeğin genelinde ve tüm alt boyutlarında hem öğretmenlerin hem de müdürlerin cinsiyetlerine göre anlamlı bir farklılık göstermemektedir. Bu bulgu literatürdeki bazı çalışmalarla da benzerlik göstermektedir (Dawson ve Rakes, 2003; Sincar ve Aslan, 2011; Balaban, 2012; Gençay, 2018; Öztaban, 2020; Hayytov, 2013; Engür, 2014; Liu, Ritzhaupt, Dawson ve Barron, 2017). Araştırmadan elde edilen böyle bir bulgudan da farklı cinsiyetlerden olsalar da eğitimcilerin teknolojinin eğitim öğretim ortamlarında kullanılması gibi konularda ortak görüşlere sahip oldukları sonucuna varılabilir.

Araştırmanın bir diğer bulgusuna göre öğretmenlerin okul müdürlerinin teknoloji liderliği rollerini gerçekleştirmelerine ilişkin algılarının hem ölçeğin genelinde hem de tüm alt boyutlarında okul müdürlerinin görev yaptığı eğitim kademesine göre anlamlı bir farklılık göstermektedir. Bu fark "insan odaklılık" ve "vizyon ve destek" alt boyutlar ile "ölçek toplam puanı" için ilkokullarda görev yapan öğretmenlerle liselerde görev yapan öğretmenler arasında ilkokullarda görev yapan öğretmenler lehinedir. "İletişim ve iş birliği" alt boyutu için ise ilkokullarda görev yapan öğretmenler ile ortaokullarda ve liselerde görev yapan öğretmenler arasında ilkokullarda görev yapan öğretmenler lehinedir. Dolayısıyla ilkokullarda görev yapan öğretmenlerin okul müdürlerinin teknoloji liderliği rollerini gerçekleştirmelerine ilişkin algıları diğer kademelerde görev yapmakta olan öğretmenlere göre daha yüksektir. Yapılan benzer araştırmalarda (Balaban, 2012; Engür, 2014; Irmak, 2015; Öztaban, 2020; Sincar, 2011) ilkokullarda görev yapan öğretmenlerin okul müdürlerinin teknoloji liderliği rollerini gerçekleştirmelerine ilişkin algılarını diğer kademelerde görev 
yapan öğretmenlere kıyasla daha yüksek bulmuştur. Araştırmadan ulaşılan bu bulgunun altında yatan sebebin ilkokullarda görev yapan öğretmenlerin diğer kademelerde görev yapan öğretmenlere kıyasla teknolojiyi eğitim ortamında daha az kullanmalarından kaynaklanabileceği ve bu nedenle de okul müdürlerini teknolojik açıdan liderlik rollerini daha yeterli düzeyde gerçekleştirdikleri düşünülmektedir. Aynı zamanda farklı eğitim kademelerinde görev yapan öğretmenlerin yöneticilerine yönelik teknoloji liderliği beklentilerinin farklı olmasının da araştırmanın bu bulgusunda etkili olabileceği düşünülmektedir.

Nitel araştırma kapsamında okul yöneticileri ile yapılan görüşmeler neticesinde ulaşılan bulgular okul yöneticilerinin okullarını küresel bir okul olarak algılamalarında en fazla etkili olan faktörün yeterli teknolojik donanıma sahip olma durumunun olduğunu bildirmiştir. Bunu ulusal ve uluslararası projeler ile yurt dışı deneyimler izlemiştir. Öte yandan okullarını küresel bir okul olarak algılamayan okul yöneticileri ise bu durumda en çok fiziki ve donanımsal eksiklikler ile maddi yetersizliklerin etkili olduğunu ifade etmiştir. Özellikle, bilgi teknolojileriyle ilişkili olmak üzere, modern bilimin ve yeni teknolojilerin bir sonucu olarak görülen küreselleşmenin (Karslen, 2002) doğrudan etkilediği kurumların başında eğitim kurumları gelmektedir (Karaman, 2010). Bu sebeple okul yöneticilerinin küreselleşme ile teknolojik donanıma sahip olmayı ilişkili görmesi manidardır. Zira, Yılmaz ve Horzum (2005)'da araştırmanın bu bulgusunu destekler nitelikte küreselleşme denildiğinde ilk akla gelen kavramlardan birinin teknolojik gelişmelerin insan hayatına olan etkisi olduğunu belirterek küreselleşmenin hızlandırıcılarından biri olan teknolojik gelişmelerin eğitim kurumlarını bu teknolojilerden yararlanmaya zorladığını ifade etmişlerdir. Öte yandan günümüzde eğitim alanında uluslararası düzeyde Erasmus, Sokrates, Comenius ve Uluslararası Bakalorya Diploma Programı (IBDP) gibi çok çeşitli programlar düzenlenir olmuştur (Sever vd., 2018). Bu etkinlikler aracılığı ile pek çok kişi farklı kültürleri yerinde tanıma ve kendi kültürünü tanıtma fırsatına sahip olmaktadır. Tüm bu uluslararası projeler ve eğitimcilerin yurt dışı deneyimleri onları küresel dünyanın bir parçası yapmaktadır (Çetin, 2015). Bu bilgilerden hareketle okul müdürlerinin okullarının küresel bir okul olma durumuna ilişkin algılarında etkili olan niteliklerin mevcut literatür tarafından da desteklendiği söylenebilir.

Nitel araştırmadan ulaşılan bir diğer bulguya göre ise okul yöneticileri eğitimde teknoloji kullanımını öğretme ve öğrenme sürecinin destekleyici bir unsuru ve eğitimin vazgeçilmez bir aracı olarak görmektedir. Literatürde eğitimde teknoloji kullanımına ilişkin yapılan çok sayıda araştırma eğitimde teknoloji kullanımının öğretme ve öğrenme sürecine olumlu etkileri olduğunu ortaya koymuştur (Courville, 2011; Çağıltay vd., 2001; Güllüpınar vd., 2013; Stošić, 2015; Yavuz ve Coşkun, 2008). Ayrıca araştırmada okul yöneticilerine göre teknolojinin eğitim sürecinde doğru kullanılması gereken bir unsur olduğu bulunmuştur. Gülcü vd. (2013)'de araştırmasında öğretmenlerin eğitim teknolojilerini eğitim sürecinde doğru ve etkili kullanmaları gerektiğini bunun içinde gerekli olan temel bilgi ve beceriye sahip olmalarının önemli olduğunu bulmuştur.

Araştırmadan elde edilen bir diğer bulguya göre katılımcıların çok büyük bir kısmı okullarındaki teknolojik alt yapının yeterli düzeyde olduğunu belirtmiştir. Ancak az sayıda da olsa okullarındaki teknolojik alt yapının yetersiz olduğunu bildiren okul yöneticisi olmuştur. Yapılan benzer araştırmalar incelendiğinde bazı araştırmalarda okulların yeterli teknolojik alt yapıya sahip olduğu bulunmuşken bazılarında da tam tersi bir durum 
bulunmuştur (Atalay ve Anagün, 2014; Johnson et al., 2016; Şendurur ve Arslan, 2017; Waite, 2004). Bu araştırmaların gerçekleştirildiği okulların bulunduğu yerleşim yerleri incelendiğinde; şehir merkezlerinde ve gelişmiş bölgelerde yer alan okulların, teknolojik alt yapı açısından kırsal bölgelerde kalan okullara kıyasla daha iyi imkanlara sahip olduğu anlaşılmaktadır. Dolayısıyla bu araştırmanın da il merkezinde bulunan okullarda yürütüldüğü göz önüne alındığında katılımcların okullarını teknolojik alt yapı açısından yeterli görmeleri beklenilen bir durum olarak değerlendirilebilir.

Araştırmanın bir diğer bulgusuna göre okul yöneticileri öğretmenlerin büyük bir kısmının eğitim süreçlerinde teknolojiyi aktif olarak kullandığını bildirmiştir. Ancak azımsanmayacak sayıda da okul yöneticisi öğretmenlerin eğitimde teknoloji kullanmaktan kaçındığını belirtmiştir. Literatürde öğretmenlerin eğitim sürecinde teknoloji kullanım durumlarına ilişkin gerek yurt için de gerekse yurt dışında yapılan araştırmalar incelendiğinde öğretmenlerin teknolojinin eğitimde kullanılmasına yönelik tutumlarının olumlu olduğu görülmektedir (Akkoyunlu, 2002; Albirini, 2004; Cüre ve Özdener, 2008; Huang \& Liaw, 2005; Seferoğlu, Akbıyık ve Bulut, 2008; Teo, 2008). Ancak az sayıda da olsa eğitimde teknoloji kullanımına yönelik olarak öğretmenlerin olumsuz inançlar taşıdığını gösteren araştırmalara rastlamak mümkünüdür (Çakıroğlu, Güven ve Akkan, 2008).

Araştırmadan ulaşılan son bulguya göre okul yöneticileri eğitimde teknoloji kullanımının öğrenmenin kalıcılığını sağlama, öğrencinin öğrenme motivasyonunu arttırma, konuya ilgisini çekme, algılamasını kolaylaştırma, zaman tasarrufu sağlama ve araştırmayı meraklandırma gibi birtakım olumlu etkileri bulunduğunu ifade etmiştir. Akkoyunlu (1998)' da eğitim sürecinde teknoloji kullanımının başlıca yararlarını öğrenmenin niteliğinde artış, öğrencilerin ve öğretmenlerin hedefe ulaşmak için harcadıkları zamanın azalması, öğretmenin etkinliğinde artış ve eğitimin maliyetinde düşüş şeklinde sıralamıştır. Öte yandan araştırmanın bu bulgusunu destekler nitelikte Rıza (2003) ve Davis (2003) eğitimde teknoloji kullanımının eğitimin kalitesini arttırdığını; Heafner (2004) ve Marzano (2009), öğrencilerin eğitim sürecinde teknoloji ile etkileşim halinde olmalarının öğrencilerin motivasyonunu arttırdığı ve böylece derslerinde daha başarılı olduklarını; Özen (2013)'te teknoloji kullanımının ders işlerken zaman kaybını önlediğini belirtmiştir. Öztürk (2006)'de eğitimde teknoloji kullanmanın eğitimin kalitesini yükseltmesinin yanında teknolojiyi anlayan geliştiren nesiller yetişmesine olanak sağladığını belirtmiştir. Eğitimde teknoloji kullanımının belirtilen bu faydalarının yanında teknoloji bağımlılı̆̆ını arttırma, öğrencilerde hazırcılı̆̆ teşvik etme, sınıf hakimiyetini zorlaştırma ve materyallerin amaç dışı kullanımı gibi bazı olumsuz etkilerinin de olduğu okul yöneticileri tarafından belirtilmiştir. Güllüpınar vd. (2013) velilerle yaptığı görüşmeler neticesinde eğitimde teknoloji kullanımının öğrencilerin okuma alışkanlığını azalttığını, sosyalleşmelerini engellediğini ve teknolojiyi amaç dışında kullanma gibi birtakım olumsuzluklarının olduğunu bulmuştur. Benzer bir araştırmayı öğretmen adayları üzerinde yürüten Dargut ve Çelik (2014)'te eğitimde teknoloji kullanımının olumsuzluklarını; tembelliğe neden olması, öğretim sürecini yavaşlatma ve öğretmenin teknoloji konusunda yeterli olmadığı durumlarda dersin kalitesinin düşmesi olarak bulmuştur.

Araştırmadan elde edilen bulgular doğrultusunda şu sonuçlara ulaşılmıştır: (i) öğretmenlerin okul müdürlerinin teknoloji liderliği rollerini gerçekleştirmelerine ilişkin algıları orta düzeydedir; (ii) okul müdürlerinin teknoloji liderliği rollerini gerçekleştirmelerine ilişkin öğretmen algıları hem öğretmenlerin hem de öğretmenlerin görev yaptıkları okul 
müdürlerinin cinsiyetlerine göre anlamlı bir farklılık göstermemektedir; (iii) ilkokullarda görev yapan öğretmenlerin okul müdürlerinin teknoloji liderliği rollerini gerçekleştirmelerine ilişkin algıları diğer kademelerde görev yapmakta olan öğretmenlere göre daha yüksektir; (iv) okul yöneticilerinin okullarını küresel bir okul olarak algılamalarında okullarının yeterli teknolojik donanıma sahip olma durumu, uluslararası projeler ve yurt dışı deneyimler etkilidir; (v) okul yöneticileri eğitimde teknoloji kullanımını öğretme ve öğrenme sürecinin destekleyici bir unsuru ve eğitimin vazgeçilmez bir aracı olarak görmektedir; (vi) okul yöneticilerinin çok büyük bir kısmı okullarındaki teknolojik alt yapının yeterli düzeyde olduğunu belirtmiştir; (vii) okul yöneticileri öğretmenlerin büyük bir kısmının eğitim süreçlerinde teknolojiyi aktif olarak kullandığını bildirmiştir; (viii) okul yöneticileri eğitimde teknoloji kullanımının öğrenmenin kalıcılığını sağlama, öğrencinin öğrenme motivasyonunu arttırma, konuya ilgisini çekme, algılamasını kolaylaştırma, zaman tasarrufu sağlama ve araştırmayı meraklandırma gibi birtakım olumlu etkilerinin yanında teknoloji bağımlılığını arttırma, öğrencilerde hazırcılığı teşvik etme, sınıf hakimiyetini zorlaştırma ve materyallerin amaç dışı kullanımı gibi bazı olumsuz etkilerinin de olduğu okul yöneticileri tarafından belirtilmiştir.

$\mathrm{Bu}$ araştırmanın bazı sınırlılıkları bulunmaktadır. Araştırmanın katılımcıları öğretmenler ve okul yöneticileridir. Araştırma Türkiye' nin gelişmiş bir şehrinin merkezinde bulunan kamuya ait okullarda gerçekleştirilmiştir. Araştırma verileri katılımcıların veri toplama araçlarına verdikleri cevaplarla sinırlıdır.

Araştırmadan elde edilen sonuçlar doğrultusunda araştırmacılara ve uygulayıcılara yönelik birtakım öneriler sunulabilir. Öğretmenlerin ve okul yöneticilerinin yanında öğrenciler ve veliler de eğitim sürecinin önemli bir parçasıdır. Dolayısıyla farklı eğitim kademelerinde öğrenim görmekte olan öğrencilerle ve onların velileri ile de benzer bir araştırma yürütülerek eğitim sürecinin farklı paydaşlarının görüşlerini inceleme fırsatı sağlanmış olur. Özel okullar ve kırsal bölgelerde bulunan okullar üzerinde benzer bir araştırma yapılabilir ve çıkan sonuçlar bu ve benzeri diğer araştırma sonuçları ile karşılaştırılabilir. Böylece imkân ve fırsat eşitsizliklerin giderilmesi için adımların atılması sağlanabilecektir. Zira günümüzde hala birçok okulda teknolojik alt yapı yetersizliği mevcuttur ve uygulayıcılara bir an önce bu eksiliklerin giderilmesi tavsiye edilmektedir. Günümüz küresel dünyasında 21.yüzyılın bireylerini yetiştirecek olan öğretmenlerin bilgi, beceri ve vizyonlarını her daim geliştirmeleri gerekmektedir. $\mathrm{Bu}$ bağlamda gerek uluslararası projelerle gerekse yurt dışı değişim programları ile öğretmenlerin kendilerini geliştirmeleri desteklenmelidir. Eğitim yöneticilerinin okullarında teknoloji kullanımı konusunda meslektaşlarına liderlik etmeleri, onlara bu konuda rehberlik etmeleri gerekmektedir. Eğitimde teknoloji kullanımı öğretmen yetiştirme sürecinde ve hizmet içi eğitim sürecinde teknolojideki gelişmelere paralel olarak güncellenmeli ve öğretmenlerin eğitimde teknoloji kullanımı teşvik edilmelidir. 


\section{Kaynakça}

Anderson, R. E. \& Dexter, S. (2005). School technology leadership: An empirical investigation of prevalence and effect. Educational Administration Quarterly, 41(1), 49-82.

Akkoyunlu, B. (1998). Ĕgitimde Teknolojik Gelişmeler. Eskişehir: Anadolu Üniversitesi Açıöğretim Fakültesi Yayınları.

Akkoyunlu, B. (2002). Öğretmenlerin internet kullanımı ve bu konudaki öğretmen görüşleri. Hacettepe Üniversitesi Eğitim Fakültesi Dergisi, 22, 1-8.

Albirini, A. A. (2004). An exploration of the factors associated with the attitudes of high school EFL teachers in Syria toward information and communication technology. Unpublished thesis The Ohio State University.

Atalay, N. \& Anagün, Ş. S. (2014). Kırsal alanlarda görev yapan sınıf öğretmenlerinin bilgi ve iletişim teknolojilerinin kullanımına ilişkin görüşleri. Eğitimde Nitel Araştırmalar Dergisi, 2(3), 9-27. [Online] http://www.enadonline.com doi: 10.14689/issn.2148-2624.1.2c3s1m

Baki, A. \& Gökçek, T. (2012). Karma yöntem araştırmalarına genel bir bakış. Elektronik Sosyal Bilimler Dergisi, 11(42), 1-21.

Balaban, N. (2012). Okul yöneticilerinin teknoloji liderliği rolleri ile bilgisayar kaygi düzeyleri arasındaki ilişkinin belirlenmesi. Yayımlanmamış yüksek lisans tezi, Anadolu Üniversitesi, Eğitim Bilimleri Enstitüsü, Eskişehir.

Bilig, S. H., Sherry, L. \& Havelock, B. (2005). Challenge 98: Sustaining the Work of a Regional Technology Integration Initiative. British Journal of Educational Technology, 36(6), 9871003.

Can, T. (2008). İlköğretim okulları yöneticilerinin teknolojik liderlik yeterlilikleri: Ankara ili Etimesgut ilçesi örneği. 8. Ulusal Eğitim Teknolojileri Kongresinde sunulan bildiri. 8. Uluslararası Eğitim Teknolojileri Sempozyumu, 06-08 May 2008, Anadolu University.

Chang, I. H. (2012). The effect of principals' technological leadership on teachers' technological literacy and teaching effectiveness in Taiwanese elementary schools. Educational Technology E Society, 15(2), 328-340.

Courville, K. (2011). Technology and Its Use in Education: Present Roles and Future Prospects. Online Submission.

Creighton, T. (2003). The Principal as Technology Leader. California: Corwin Press Inc.

Creswell, J. W. (2003). Research design: Qualitative, quantitative, and mixed methods approaches (2. Bask1). Thousand Oaks, CA: Sage.

Cüre, F. \& Özdener, N. (2008). Öğretmenlerin bilgi ve iletişim teknolojileri (BİT) uygulama başarıları ve BİT'e yönelik tutumları. Hacettepe Üniversitesi Ĕ̆itim Fakültesi Dergisi, 34, 4153.

Çağıltay, K, Çakıroğlu, J., Çağıltay N. \& Çakıroğlu E. (2001). Öğretimde bilgisayar kullanımına ilişkin öğretmen görüşleri. Hacettepe Eğitim Dergisi, 21 (1). 19-28.

Çakıroğlu, Ü., Güven, B. \& Akkan, Y. (2008). Matematik öğretmenlerinin matematik eğitiminde bilgisayar kullanımına yönelik inançlarının incelenmesi. Hacettepe Üniversitesi Ĕ̈itim Fakültesi Dergisi, 35, 38-52. 
Çalık, T. \& Sezgin, F. (2005). Küreselleşme, bilgi toplumu ve eğitim. Kastamonu Ĕ̆gitim Dergisi, 13(1), 55-66.

Çalık, T., Çoban, Ö. \& Özdemir, N. (2019). Okul Yöneticilerinin Teknolojik Liderlik Öz Yeterlikleri ve Kişilik Özellikleri Arasındaki İlişkinin İncelenmesi. Ankara Üniversitesi Eğitim Bilimleri Fakültesi Dergisi, 52(1), 83-106.

Çetin, O. (2015). Küreselleşmenin eğitimin farklı boyutları üzerindeki etkileri. Çağdaş Yönetim Bilimleri Dergisi, 2(1), 75-93.

Dağlı, A. (2007). Küreselleşme karşısında Türk eğitim sistemi. Dicle Üniversitesi Ziya Gökalp Ĕ̆̈itim Fakültesi Dergisi, (9)1-13.

Dargut, T. \& Çelik, G. (2014). Türkçe öğretmeni adaylarının eğitimde teknoloji kullanımına ilişkin tutum ve düşünceleri. Ana Dili Eğitimi Dergisi, 2(2), 28-41.

Davis, N. (2003). Technology in Teacher Education in the USA: What Makes For Sustainable Good Practice. Technology, Pedagogy and Education, 12, 59-73.

Dawson, C. \& Rakes, G. C. (2003). The influence of principals' technology training on the integration of technology into schools. Journal of research on Technology in Education, 36(1), 29-49.3f

Doğan, E. (2002). Eğitimde Küreselleşme. Eğitim Araştırmaları. Ankara: Anı Yayıncılık.

Engür, A. (2014). Teknoloji öğretmenlerinin okul müdürlerinin teknolojik liderlik becerileri hakkindaki görüşleri (Yüksek Lisans Tezi), Akdeniz Üniversitesi Eğitim Bilimleri Enstitüsü, Antalya.

Erden, H. \& Erden, A. (2007). Teachers' perception in relation to principles'technology leadership: 5 primary school cases in Turkish Republic of Northern Cyprus. 7th International Educational Technology (IETC)Conference. 03-05 May 2007, North Cyprus: Near East University.

Eren-Şişman, E. (2010). İlköğretim okul müdürlerinin eğitim teknolojilerini sağlama ve kullanmada gösterdikleri liderlik davranışları. Yayınlanmamış Doktora Tezi, Anadolu üniversitesi Eğitim Bilimleri Enstitüsü, Eskişehir.

Gençay, A. (2018). Illkokul ve ortaokul yöneticilerinin teknoloji liderliğine ilişkin yeterlikleri (Keçiören ilçesi örneği) (Yüksek Lisans tezi)., Yıldız Teknik Üniversitesi Sosyal Bilimleri Enstitüsü, İstanbul.

Göksoy, S. (2017). Okulların altyapı yeterliliği. Uluslararası Liderlik Ĕ̆itimi Dergisi, 1(1), 9-15.

Greene, J. C., Caracelli, V. J. \& Graham, W. F. (1989). Toward a conceptual framework for mixed-method evaluation designs. Educational evaluation and policy analysis, 11(3), 255-274.

Gülcü, A., Solak, M., Aydın, S. \& Koçak, Ö. (2013). İlköğretimde görev yapan branş öğretmenlerinin eğitimde teknoloji kullanımına ilişkin görüşleri. Electronic Turkish Studies, 8(6), 195-213

Güllüpınar, F., Kuzu, A. O., Dursun, A., Kert, A. \& Gultekin, M. (2013). Milli egitimde teknoloji kullanimi ve sonuclari: Velilerin bakıs acisindan fatih projesi'nin pilot uygulamasinin degerlendirilmesi. Journal of Social Sciences, 30, 195-216. 
Hayytov, D. (2013). Eğitim yöneticilerinin teknoloji liderliği yeterlik algilari ile öğretmenlerin teknolojiye yönelik tutumlari arasindaki ilişki (Yüksek Lisans Tezi), Gazi Üniversitesi, Eğitim Bilimleri Enstitüsü, Ankara

Heafner, T. (2004). Using technology to motivate students to learn social studies. Contemporary Issue in Technology and Teacher Education, 4(1), 42-53.

Hsieh, C.C., Yen, H.C. \& Kuan, L.Y. (2014). The Relationship among principals' technology leadership, teaching innovation, and students' academic optimism in elementary schools. Presented at International Conferences on Education Technologies (ICEduTech) and Sustainability, Technology and Education (STE) from https://www.learntechlib.org/p/158345/.

Huang, H. M. \& Liaw, S. S. (2005). Exploring users' attitudes and intentions toward the web as a survey tool. Computers in human behavior, 21(5), 729-743.

Irmak, M. (2015). İlkokul ve ortaokul öğretmenlerinin, yöneticilerinin "teknoloji liderliği" düzeylerine ilişkin algilari (Yüksek Lisans Tezi), Pamukkale Üniversitesi, Eğitim Bilimleri Enstitüsü, Denizli.

Johnson, A. M., Jacovina, M. E., Russell, D. E. \& Soto, C. M. (2016). Challenges and solutions when using technologies in the classroom. In S. A. Crossley \& D. S. McNamara (Eds.) Adaptive educational technologies for literacy instruction (pp. 13-29). New York: Taylor \& Francis. Published with acknowledgment of federal support.

Kalayc1, Ş. (2014). SPSS uygulamalı çok değgişkenli istatistik teknikleri (6nd). Ankara: Asil Publishing.

Karaman, K. (2010). Küreselleşme ve eğitim. Zeitschrift für die Welt der Türken/Journal of World of Turks, 2(3), 131-144.

Kozloski, K. C. (2007). Principal leadership fortechnology integration: A study of principal technology leadership. Unpublished doctoral dissertation, Drexel University, the United States.

Liu, F., Ritzhaupt, A. D., Dawson, K. \& Barron, A. E. (2017). Explaining Technology Integration in K-12 Classrooms: A Multilevel Path Analysis Model. Educational Technology Research and Development, 65(4), 795-813.

Macaulay, L. S. (2009). Elementary principals as technology instructional. In E-Learn: World Conference on E-Learning in Corporate, Government, Healthcare, and Higher Education (pp. 20082017). Association for the Advancement of Computing in Education (AACE).

Marzano, R.J. (2009). Teaching with interactive whiteboards. Educational Leadership, 67(3), 8082.

McLeod S. ve Richardson J. W. (2011). The dearth of technology leadership coverage. Journal of School Leadership, 21, 216-240.

Miles, M, B. \& Huberman, A. M. (1994). Qualitative data analysis: An expanded sourcebook. (2nd ed). Thousand Oaks, CA: Sage.

Özen, R. (2013). Öğretmen adaylarının eğitimi ve teknoloji kullanımı: Bir durum çalışması. International Journal of Human Sciences, 10(2), 147-162.

Öztaban, A. (2020). Okul yöneticilerinin teknoloji liderliği rollerini yerine getirme düzeyleri. Yüksek Lisans Tezi. Aydın: Adnan Menderes Üniversitesi, Sosyal Bilimler Enstitüsü. 
Öztürk, T. (2006). Sosyal bilgiler öğretmen adaylarının eğitimde teknoloji kullanımına yönelik yeterliliklerinin değerlendirilmesi (Balıkesir İli örneği). Yayımlanmamış Yüksek Lisans Tezi. Ankara Gazi Üniversitesi EBF.

Power, N. C. (2000). Global trends in education. International Education Journal, (3)1-6.

Rıza, E. (2003). Eğitim teknolojisi uygulamaları ve materyal geliştirme. ISBN: 975- 96446-1-4-448 s.

Richardson, J. W., Bathon, J., Flora, K. L. \& Lewis, W. D. (2012). NETS-A Scholarship: A review of published literature. Journal of Research on Technology in Education, 45, 131-151.

Seferoğlu, S. S., Akbıyık, C. \& Bulut, M. (2008). İlköğretim öğretmenlerinin ve öğretmen adaylarının bilgisayarın öğrenme/öğretme sürecinde kullanımı ile ilgili görüşleri, Hacettepe Üniversitesi Ĕ̆itim Fakültesi Dergisi, 35, 273-283.

Sever, D., Baldan, B., Tuğlu, B., Kabaoğlu, K. \& Hamzaj, Y. A. (2018). Küreselleşme sürecinde eğitim alanında atılan adımlar: Türkiye ve eğitimde başarılı ülke örnekleri. Elementary Education Online, 17(3).

Sezer, B. (2011). İlköğretim okul yöneticilerinin teknoloji liderliği rollerine ilişkin yeterlikleri (Yüksek Lisans Tezi), Ankara Üniversitesi Eğitim Bilimleri Enstitüsü, Ankara.

Sincar, M. (2009). İlköğretim okulu yöneticilerinin teknoloji liderliği rollerine iliskin bir inceleme (Gaziantep İli Örneği) (Doktora Tezi), İnönü Üniversitesi, Sosyal Bilimler Enstitüsü, Malatya.

Sincar, M. \& Aslan, B. (2011). İlköğretim okulu yöneticilerinin teknoloji liderliği rollerine ilişkin öğretmen görüşleri. Gaziantep University-Journal of Social Sciences, 10(1), 571-595.

Stošić, L. (2015). The importance of educational technology in teaching. International Journal of Cognitive Research in Science, Engineering and Education, 3(1).

Şendurur, P. \& Arslan, S. (2017). Eğitimde teknoloji entegrasyonunu etkileyen faktörlerdeki değişim. Mehmet Akif Ersoy Üniversitesi Eğitim Fakültesi Dergisi, (43), 25-50.

Teo, T. (2008). Assessing the computer attitudes of students: An Asian perspective. Journal of Computers in Human Behaviour, 24, 1634-1642

Waite, S. (2004). Tools for the job: A report of two surveys of information and communications technology training and use for literacy in primary schools in the West of England. Journal of Computer Assisted Learning, 20 (1), 11-20.

Watts, C. D. (2009). Technology leadership, school climate, and technology integration: a correlation study in K-12 public schools. Doctoral Dissertation. The University of Alabama, Tuscaloosa.

Yavuz, S. \& Coşkun, E. A. (2008). Sınıf öğretmenliği öğrencilerinin eğitimde teknoloji kullanımına ilişkin tutum ve düşünceleri. Hacettepe Üniversitesi Eğitim Fakültesi Dergisi, 34(34), 276-286.

Yıldırım, A. \& Şimşek, H. (2013). Sosyal bilimlerde nitel araştırma yöntemleri (Genişletilmiş 9. Baskı). Ankara: Seçkin Yayıncılık.

Yilmaz, K. \& Horzum, M. B. (2005). Küreselleşme, bilgi teknolojileri ve üniversite. İnönü Üniversitesi Eğitim Fakültesi Dergisi, 6(10), 103-121.

Yu, C. \& Durrington, V. A. (2006). Technology standards for school administrators: An analysis of practicing and aspiring administrators' perceived ability to perform the standards. NASSP Bulletin, 90 (4), 301-317. 